\title{
Prognostic factors in craniocerebral gunshot wounds: Analysis of 30 patients from the neurosurgical viewpoint
}

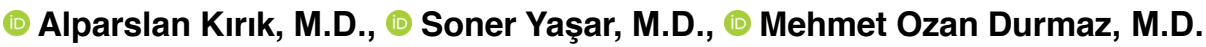

Department of Neurosurgery, University of Health Sciences Gülhane Faculty of Medicine, Ankara-Turkey

\begin{abstract}
BACKGROUND: Craniocerebral gunshot wounds (CGW) are the most lethal injuries of the cranium. CGW is mostly secondary to military conflicts but may also be seen in civilian life. These injuries also have severe consequences, such as epilepsy, hydrocephalus, infection and late-term cognitive dysfunctions. The present study aims to present our series of CGW and to discuss the prognostic factors and consequences of these injuries.
\end{abstract}

METHODS: The data of patients who were treated in our department for CGW between 20II and 2019 were retrospectively reviewed in this study. The injury type, wounding site, surgical management and outcomes were analyzed. Radiological evaluation was also performed.

RESULTS: Thirty patients were treated with the diagnosis of CGW. All of the patients were male and the mean age was 27.9 years. The frontal lobe was affected in $12(40 \%)$ patients, while temporal lobe in eight, occipital lobe in six, parietal lobe in three, and posterior fossa in one patients. Twenty-three patients underwent surgical treatment, seven patients were treated conservatively. Thirteen (43.3\%) patients died despite the treatment.

CONCLUSION: Mortality in CGW is high. Ventricular injuries, bihemispheric or midline injuries, perforating injuries, brain stem injuries and low GCS score at admission are prognostic factors for CGW. Appropriate management is mandatory to obtain a better clinical outcome.

Keywords: Craniocerebral; gunshot; injury; outcome; surgery.

\section{INTRODUCTION}

Craniocerebral gunshot wounds (CGW) are increasing medical problems in a military setting, as well as in civilian practice. ${ }^{[1-5]}$ Especially in recent years, the increasing incidents of violence, civil wars and terrorism in cities have made CGW even more important. ${ }^{[6-9]}$ These injuries are the most lethal form of all firearm injuries, and the treatment principles are still controversial. ${ }^{[10,1]]}$ Minimal invasive approaches are suggested by many authors, while aggressive surgical methods are also advocated to prevent the mortality of patients. ${ }^{[12-14]}$ Attacks, suicide attempts and accidents are the most common causes of CGW. In wartime or terrorist actions, this type of injuries has the highest mortality and morbidity. ${ }^{[6]}$
The management of CGW is of paramount importance. Patient's history, general physical and neurological conditions, and appropriate radiological examinations play a key role in the correct and effective treatment of the patients. ${ }^{[3,15,16]}$ First aid in the field may save the life of patients if it is administered appropriately. ${ }^{[5]}$ Detailed radiological evaluation and intensive care management are the hospital steps of the CGW management. ${ }^{[11]}$

The present study aims to present our experience with the CGW and to determine the possible prognostic factors of such injuries. The clinical, surgical and radiological, as well as surgical data, were collected and analyzed. The results were compared with the current literature.

Cite this article as: Kırık A, Yaşar S, Durmaz MO. Prognostic factors in craniocerebral gunshot wounds: Analysis of 30 patients from the neurosurgical viewpoint. Ulus Travma Acil Cerrahi Derg 2020;26:859-864.

Address for correspondence: Alparslan Kırık, M.D.

Sağılık Bilimleri Üniversitesi Gülhane Tıp Fakültesi, Beyin ve Sinir Cerrahisi Anabilim Dalı, Ankara, Turkey

Tel: +90 312 - 3045307 E-mail: dr_alper@hotmail.com

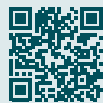

Ulus Travma Acil Cerrahi Derg 2020;26(6):859-864 DOI: 10.14744/tjtes.2020.89947 Submitted: 28.09.2019 Accepted: II.02.2020 Online: 21.10 .2020

Copyright 2020 Turkish Association of Trauma and Emergency Surgery 


\section{MATERIALS AND METHODS}

The data of patients who underwent treatment for CGW were reviewed retrospectively. The clinical presentation, management method, surgical technique and clinical outcomes were analyzed. Ethical approval was obtained for this retrospective study. The demographic data are presented in Table I. Computed tomography (CT) was performed in all patients just after admission to our department. Additional radiological examinations, such as magnetic resonance imaging (MRI) or angiography, were performed in selected patients who had the suspect of abscess or traumatic aneurysm. MRI was not performed in patients with the metal retained fragment.

Surgical treatment was performed in patients with active bleeding, open cranial injury and worsening neurological conditions. Debridement of necrotic tissues, stopping the active bleedings, dural repair and skin closure were performed as standard surgical procedures. Deep-seated foreign bodies were left in place if there was no sign of abscess or empyema. Infection prophylaxis was maintained with wide spectrum of antibiotics. Abscesses that were developed in the late phase of treatment were also drained with surgical methods. Cranioplasty was carried out at least one year after the last surgery. Computer-based custom made titanium implants were used for cranioplasty.

\section{RESULTS}

Thirty patients were treated with the diagnosis of CGW in the Department of Neurosurgery of our institution between $201 \mathrm{I}$ and 2019. All of them were male, and the mean age was 27.9 years, ranging between 19 and 48 years. Twenty-two of them injured in distant cities and transferred to our department after the first aid for further management and eight patients were injured in our city and referred to our department just after the injury. Glasgow coma scale (GCS) score at admission was between three and eight in 16 patients, while GCS score was between nine and 15 in 14 patients. The frontal lobe was the most affected site of the brain, followed by temporal, occipital, parietal lobes and posterior fossa (Figs. I and 2) (Table 2). Surgical treatment was in 23 (76.6\%) patients, while seven patients underwent conservative (wound closure only) management. Perforating injuries were observed in five patients (Figs. 3 and 4). Three of the seven pa-
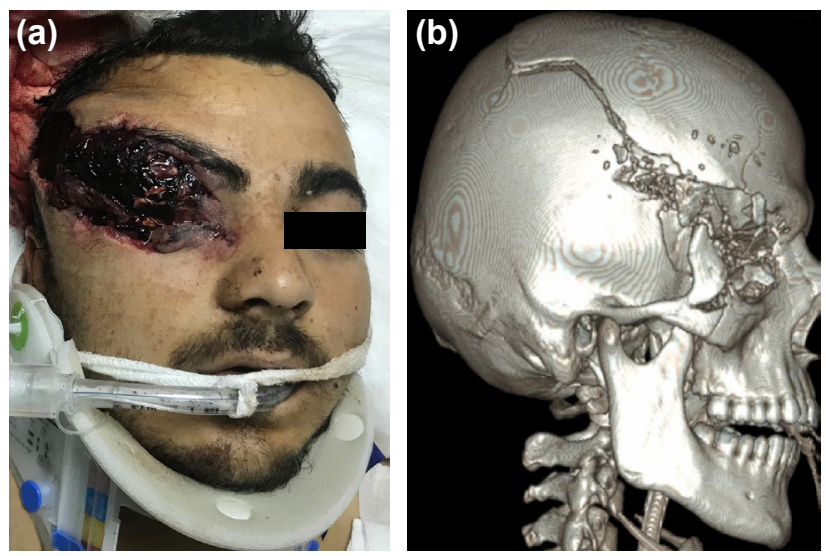

Figure 1. (a) A patient with right orbitofrontotemporal fracture secondary to the explosion. (b) 3-D CT scan shows right orbital perforation and fracture lines.
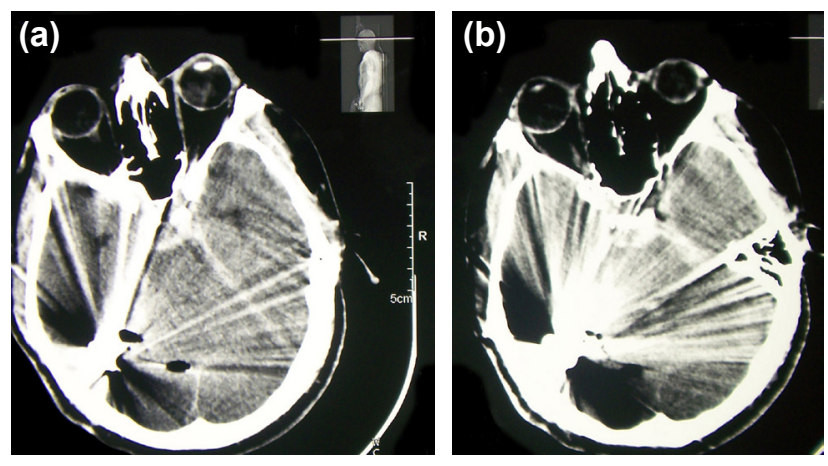

Figure 2. (a, b) Axial CT scans of a patient with right occipital gunshot wound secondary to bullet penetration. The metal artefact is obvious.

tients with conservative treatment had a diffuse brain injury, swelling or herniation at the time of admission (Fig. 5), while the other four patients had a tangential injury with minimal

Table 2. Sites of the injury

\begin{tabular}{lc}
\hline Site & Number \\
\hline Frontal lobe & 12 \\
Temporal lobe & 8 \\
Occipital lobe & 6 \\
Parietal lobe & 3 \\
Posterior fossa & 1 \\
\hline
\end{tabular}

Table I. The demographic and surgical features of the patients

\begin{tabular}{lcccccc}
\hline Weapon & Number & Mean age (years) & Male/Female & Military/Civilian & Surgery/Conservative & Death \\
\hline Rifle (bullet) & 4 & 20.3 & $4 / 0$ & $4 / 0$ & $3 / 1$ & 2 \\
Handgun (bullet) & $\mathrm{I}$ & 32 & $1 / 0$ & $0 / 1$ & $0 / 1$ & 1 \\
Handmade explosive (shrapnels) & 25 & 25.8 & $25 / 0$ & $21 / 4$ & $20 / 5$ & 10 \\
Total & 30 & 27.9 & $30 / 0$ & $25 / 5$ & $23 / 7$ & 13 \\
\hline
\end{tabular}




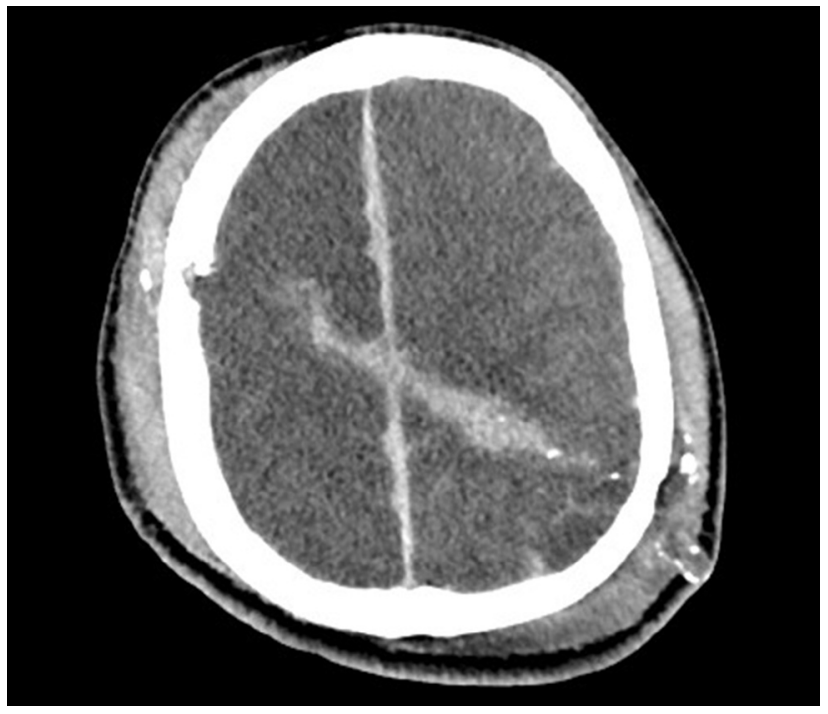

Figure 3. Axial CT scan of a patient with bihemispheric CGW.
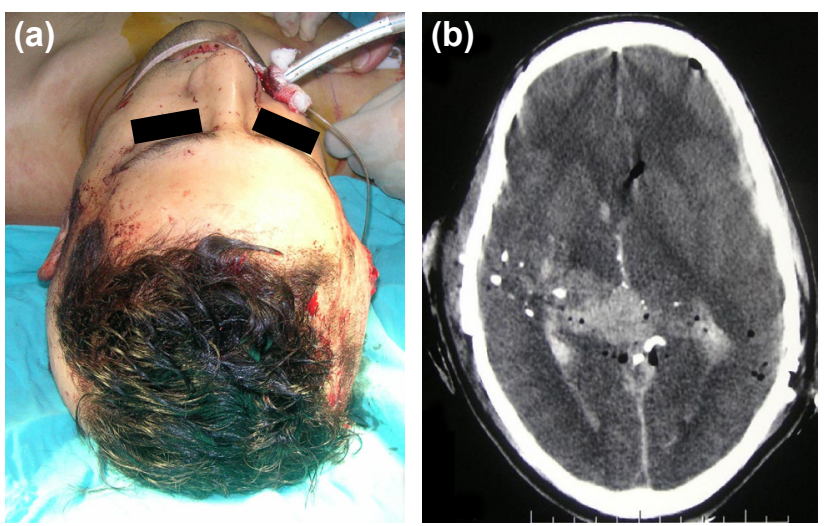

Figure 4. (a) A patient with perforating CGW secondary to the suicide attempt. (b) Axial CT scan shows the entrance and exit points of the bullet wound trajectory and bone fragments into the cranium.
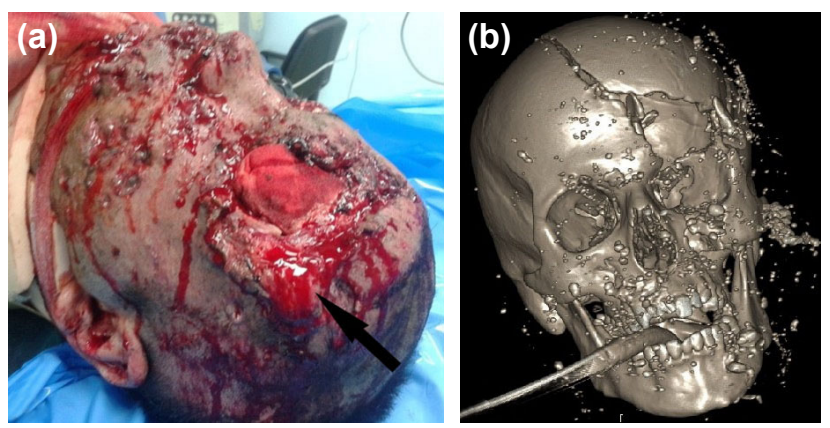

Figure 5. (a) A patient with left fronto-orbital CGW secondary to landmine explosion). (b) 3-D CT scan showed multiple shrapnels and fracture lines on the cranium.

cerebral contusion and GCS score was 15 at admission. Thus, there was no need for surgery.

Thirteen (43.3\%) patients died despite surgical or medical treatment. Ten of them had GSC score at admission between three and eight, three patients had a diffuse brain injury and underwent decompressive craniectomy. Duraplasty was per-
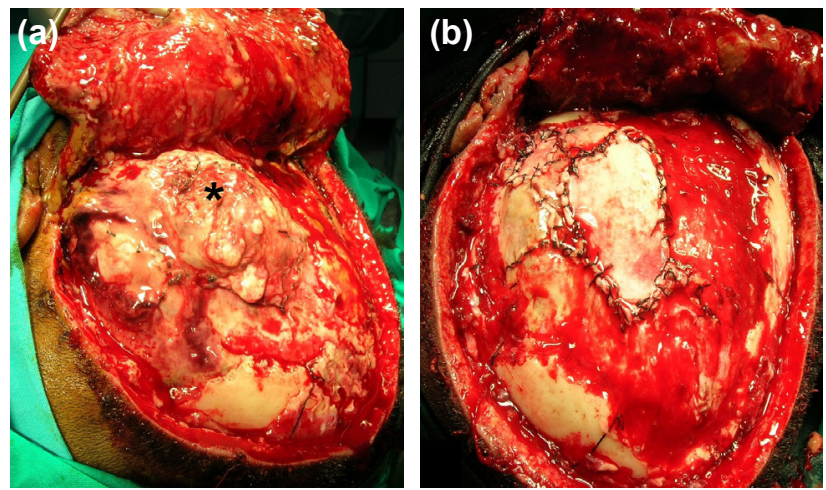

Figure 6. (a) Intraoperative view of a patient with CGW. The necrotic brain tissue $\left({ }^{*}\right)$ was herniated through the dura mater defect. (b) The necrotic brain tissue was removed and the duraplasty was performed with synthetic dural substitute.

formed in 20 patients (Fig. 6, Table 3). Cerebrospinal fluid (CSF) fistula was observed in two patients after surgery and treated conservatively. Postoperative wound infection was observed in five patients and treated using antibiotics. Five patients received anticonvulsive treatment due to the development of posttraumatic epilepsy (Table 4). Eight patients underwent custom-made computer-based cranioplasty with titanium implants.

\section{DISCUSSION}

We presented the results of 30 patients with CGW. The demographic, radiological and surgical data were shared. Our mortality rate was $43.3 \%$ and the most common causes of death were diffuse brain injury and low GCS score at admission.

CGW causes high mortality and morbidity due to their destructive properties on the central nervous system (CNS)

Table 3. Types of the surgical management

\begin{tabular}{lc}
\hline Surgery types & Number \\
\hline Only wound closure & 7 \\
Necrotic tissue debridement with intact dura mater & 3 \\
Duraplasty & 12 \\
Debridement+duraplasty & 8 \\
\hline
\end{tabular}

Table 4. Outcome and complications of the 30 patients with craniocerebral gunshot wounds

\begin{tabular}{lc}
\hline Outcome & Number \\
\hline Died & 13 \\
Cerebrospinal fluid fistula & 2 \\
Infection & 5 \\
Epilepsy & 5 \\
\hline
\end{tabular}


structures. Patients with CGW need special care and their treatment is quite challenging. ${ }^{[17-19]}$ These injuries are classified according to the type of weapon and the type of injury. For example, military-type penetrating injuries more often arise from shrapnel and high-speed projectiles, while civilian-type penetrating injuries mostly arise from low-velocity guns. ${ }^{[5,6,12,17]}$ In addition to the kinetic energy of the bullet or wounding body, the shape of the wounder, the angle of incidence, and the tissues through which it passes are effective on the penetration of the wounding body. ${ }^{[17]}$

The frequency of CGW varies according to the geographical area, socioeconomic conditions and cultural differences. ${ }^{[17]}$ The incidence of CGW is higher, especially in societies where guns are easy to acquire and violence tendencies are at the forefront. CGW accounts for 35\% of deaths under the age of 45 from brain damage. We should note that $2 / 3$ of these patients die before being hospitalized. ${ }^{[6,9,17]}$ In the United States, the annual mortality rate from head injuries due to gunshot wounds is $2-4 / 100000 \cdot{ }^{[10,17]}$ It is also important which region of the brain is affected in such injuries. Although the frontal lobe is usually the most commonly affected area, the posterior fossa and brain stem are the least affected areas. ${ }^{[2,10,20]}$ In our series, the frontal lobe is mostly injured, this site was followed by the other brain lobes. Ventricular and brain stem injuries are the most lethal forms of CGW. ${ }^{[10,11,20]}$

Radiology is an important step in patient evaluation with CGW. Plain x-rays and CT scans are crucial for the determination of retained bone and metal fragments (Fig. 2). Initial CT scan shows brain tissue injury, hemorrhages, fragments, edema and infection if performed in the late period of injury. ${ }^{[7,17]}$ In case of injuries with landmines or grenades, small shrapnels cause significant injuries in the brain and these particles can be easily detected by CT scans. ${ }^{[21]}$ However, metal fragments may also cause significant artefacts that may obscure possible hemorrhages in the brain. In such cases, plain skull $x$-rays are helpful to determine the size of the metal fragment. MRI is usually performed in the late period of injury to determine the size of brain damage, the presence of late brain abscess, or any focus or epilepsy. ${ }^{[4,18,22]}$ It should not be forgotten that MRI is contraindicated in patients with metal fragments within the skull.

Penetrating injuries usually arise from low-speed projectiles, such as shrapnels (Figs. 3, 4). Some of the kinetic energy of the projectile is transferred to the brain and some of it is absorbed by the skull. ${ }^{[6,17]}$ These injuries may result in focal brain contusion, laceration or intracerebral hematoma. Dispersion of bullet fragments or fractured bone fragments into the brain is rare. The prognosis is better in these injuries because brain damage is relatively limited. Landmine and grenade injuries in military setting cause penetrating CGW (Fig. 5). However, perforating injuries affect both sides of the head and is the most destructive form of CGW.[6,17] They usually occur with high-speed projectiles or close-up CGW with a suicide attempt. The exit point of the bullet is larger than the entry point. Exploding and disintegrating bone fragments cause extensive neuronal damage in the brain. Shock waves affect the brain stem, causing impaired respiratory and circulatory system functions and death. ${ }^{[17]}$ In our series, 25 patients had a penetrating type of CGW and five patients had a perforating type of the CGW. Significant brain damage was observed in our patients with perforating CGW and low GCS score was the common feature of these patients.

Management of each patient should be done based on the clinical, physical and radiological evaluation. ${ }^{[6]}$ Open wounds with active bleeding and brain damage should be operated as soon as possible to save the life of the patient. ${ }^{[1,2,11,17]}$ Aggressive surgical treatment is not helpful in patients with GCS score 3 and who have impaired brain stem functions. ${ }^{[17]}$ Debridement of necrotic brain tissues and stopping the active bleedings are the main aims of the surgery. Foreign bodies or bone fragments on the brain surface are also collected and the dura edges can be found with some amount of craniectomy. ${ }^{[10,11,15]}$ This is necessary for proper closure of dura mater or duraplasty (Fig. 6). Artificial materials or allografts may be used for dural closure. This prevents a possible CSF leak and infection after surgery. ${ }^{[10,17]}$ In addition, tetanus prophylaxis should be performed associated with prophylactic antibiotics and anticonvulsive therapy. ${ }^{[8,23]}$ The standard surgical treatment of intracranial hypertension is external ventricular drainage (EVD). If intracranial pressure is high despite EVD, the damaged frontal or temporal lobe can be partially excised or a decompressive craniectomy may be performed. [24] Prophylactic antibiotics can be continued for 10-14 days and anticonvulsive therapy for 6-12 months. ${ }^{[5,17,19,22,25]}$ In our series, we operated 23 patients with CGW. We performed the afformentioned methods and obtained satisfactory clinical outcomes.

Epilepsy, intracranial infection and sinking skin flap syndrome are late complications of $\mathrm{CGW}^{[6,17,26]}$ Anticonvulsive therapy may be administered after surgery or after the first seizure of the patient, which depends on the surgeon and electrophysiological findings after discharge. Antibiotics may be continued if there are contrast-enhancing lesions in the brain. [22,27] Headache, neurological deficits and seizures may be the symptoms of sinking skin flap syndrome in patients with large cranial defects. ${ }^{[3,10,17,22,28]}$ These defects should be closed using synthetic materials, such as methyl methacrylate, porous polyethylene or titanium. In addition, this closure should be delayed until the first year of injury due to the dirty nature of CGW. In our series, we performed custom-made titanium cranioplasty in eight patients with large cranium defects and obtained good cosmetic results. These cranioplasty materials were manufactured in the medical design and production center of our institution.

Prediction of prognosis is important in the management of the CGW. In all studies, the GCS score was found to be the 
most important factor in determining the prognosis of the patient and the effectiveness of surgical treatment. ${ }^{[10,11,15,17,19,20,29]}$ Pupillary changes, systemic shock, presence of infection, internal organ injuries and coagulation disorders increase the mortality of patients with higher GCS score. ${ }^{[24]}$ Ventricular injuries, bihemispheric or midline injuries, large vessel injuries, and brain stem injuries increase the mortality of patients with CGW. ${ }^{[17,18,20,23,29-31]}$ Orbital and maxillofacial injuries may be associated with CGW and must be evaluated precisely by the surgeon to avoid further morbidities. ${ }^{[6,14,17,32]}$

The major limitations of our study are the lack of long term follow-up period and the small number of the patient population.

\section{Conclusion}

In the management of the CGW:

I) Rapid neurological and radiological evaluation should be performed.

2) Intracranial hematomas should be evacuated with the debridement of necrotic tissues and haemostasis should be provided as soon as possible.

3) Easily accessible superficial or embedded bone and bullet fragments and foreign bodies should be removed.

4) If possible, the dura should be closed primarily or by using autografts or artificial materials.

5) In case of postoperative CSF leakage, lumbar drainage should be applied immediately, and if the leakage does not stop within a few days, the patient should be re-operated,

6) Rehabilitation of patients with neurological deficits should be started as soon as possible.

7) Cranioplasty should be planned at least 12 months after the injury and custom-made implants should be preferred to obtain better cosmetic results.

8) Ventricular injuries, bihemispheric or midline injuries, perforating injuries, brain stem injuries and low GCS scale at admission are prognostic factors for the CGW.

Ethics Committee Approval: Turkish General Staff Gülhane Military Medical Academy Command Ethics Committee granted approval for this study (date: 08.06 .2016 , number: 2016/331).

Peer-review: Internally peer-reviewed.

Authorship Contributions: Concept: A.K.; Design: A.K., S.Y.; Supervision: M.O.D.; Materials: S.Y.; Data: A.K., S.Y.; Analysis: S.Y.; Literature search: M.O.D.; Writing: A.K.; Critical revision: M.O.D.

\section{Conflict of Interest: None declared.}

Financial Disclosure: The authors declared that this study has received no financial support.

\section{REFERENCES}

1. Alvis-Miranda HR, Adie Villafañe R, Rojas A, Alcala-Cerra G, Moscote-Salazar LR. Management of Craniocerebral Gunshot Injuries:
A Review. Korean J Neurotrauma 2015;11:35-43. [CrossRef]

2. Carey ME. Analysis of wounds incurred by U.S. Army Seventh Corps personnel treated in Corps hospitals during Operation Desert Storm, February 20 to March 10, 1991. J Trauma 1996;40:S165-9. [CrossRef]

3. George ED, Dagi TF. Military penetrating craniocerebral injuries. Applications to civilian triage and management. Neurosurg Clin N Am 1995;6:753-9. [CrossRef]

4. Kong V, Odendaal J, Sartorius B, Clarke D, Brysiewicz P, Jerome E, et al. Civilian cerebral gunshot wounds: a South African experience. ANZ J Surg 2017;87:186-9. [CrossRef]

5. Stone JL, Lichtor T, Fitzgerald LF. Gunshot wounds to the head in civilian practice. Neurosurgery 1995;37:1104-12. [CrossRef]

6. Izci Y, Tehli O. Cranial and Spinal Cord Injuries in Terror and War [Article in Turkish].Okmeydanı Tip Derg 2017;33:21-39. [CrossRef]

7. Jamous MA. Outcome of Craniocerebral Penetrating Injuries: Experience from the Syrian War. J Neurol Surg A Cent Eur Neurosurg 2019;80:345-52. [CrossRef]

8. Joubert C, Sellier A, Morvan JB, Beucler N, Bordes J, Dagain A. Vacuum-assisted closure (VAC) for craniocerebral wounds in severely injured patients: technical note of a damage control procedure. J R Army Med Corps 2019;165:e1. [CrossRef]

9. Secer HI, Gonul E, Izci Y. Head injuries due to landmines. Acta Neurochir (Wien) 2007;149:777-82. [CrossRef]

10. Izci Y, Kayali H, Daneyemez M, Koksel T, Cerrahoglu K. The clinical, radiological and surgical characteristics of supratentorial penetrating craniocerebral injuries: a retrospective clinical study. Tohoku J Exp Med 2003;201:39-46. [CrossRef]

11. Izci Y, Kayali H, Daneyemez M, Koksel T. Comparison of clinical outcomes between anteroposterior and lateral penetrating craniocerebral gunshot wounds. Emerg Med J 2005;22:409-10. [CrossRef]

12. Bakir A, Temiz C, Umur S, Aydin V, Torun F. High-velocity gunshot wounds to the head: analysis of 135 patients. Neurol Med Chir (Tokyo) 2005;45:281-7. [CrossRef]

13. Coşar A, Gönül E, Kurt E, Gönül M, Taşar M, Yetişer S. Craniocerebral gunshot wounds: results of less aggressive surgery and complications. Minim Invasive Neurosurg 2005;48:113-8. [CrossRef]

14. Solmaz I, Kural C, Temiz C, Seçer HI, Düz B, Gönül E, et al. Traumatic brain injury due to gunshot wounds: a single institution's experience with 442 consecutive patients. Turk Neurosurg 2009;19:216-23.

15. Joseph B, Aziz H, Pandit V, Kulvatunyou N, O’Keeffe T, Wynne J, et al. Improving survival rates after civilian gunshot wounds to the brain. J Am Coll Surg 2014;218:58-65. [CrossRef]

16. Kong VY, Oosthuizen GV, Sartorious B, Bruce JL, Laing GL, Weale R, et al. Validation of the Baragwanath mortality prediction score for cerebral gunshot wounds: the Pietermaritzburg experience. Eur J Trauma Emerg Surg 2018;44:615-20. [CrossRef]

17. Gonul E, Secer HI, Izci Y. Cranial gunshot wounds. In: Gonul E, Izci Y, editors. Gunshot Injuries in Neurosurgery. Ankara, Bulus Tasarim; 2013.p.45-78.

18. Hazama A, Ripa V, Kwon CS, Abouelleil M, Hall W, Chin L. Full Recovery After a Bihemispheric Gunshot Wound to the Head: Case Report, Clinical Management, and Literature Review. World Neurosurg 2018;117:309-14. [CrossRef]

19. Kaufman HH. Care and variations in the care of patients with gunshot wounds to the brain. Neurosurg Clin N Am 1995;6:727-39. [CrossRef]

20. Erdogan E, Izci Y, Gonul E, Timurkaynak E. Ventricular injury following cranial gunshot wounds: clinical study. Mil Med 2004;169:691-5.

21. Karaca MA, Kartal ND, Erbil B, Öztürk E, Kunt MM, Şahin TT, et al. Evaluation of gunshot wounds in the emergency department. Ulus Trav- 
ma Acil Cerrahi Derg 2015;21:248-55. [CrossRef]

22. Janković S, Bradarić N, Busić Z, Dujić Z, Andelinović S, Primorac D. Early intracranial infections after brain missile injuries--the role of computer tomography in diagnosis and treatment. Acta Med Croatica 1997;51:233-7.

23. Wei LF, Wang SS, Jing JJ, Zheng ZC, Gao JX, Liu Z, et al. Surgical therapy for craniocerebral firearm injury. Turk Neurosurg 2013;23:491-7.

24. Roberts SA, Toman E, Belli A, Midwinter MJ. Decompressive craniectomy and cranioplasty: experience and outcomes in deployed UK military personnel. Br J Neurosurg 2016;30:529-35. [CrossRef]

25. Melada A, Marcikić M, Mrak G, Stimac D, Sćap M. Cerebrospinal fluid fistula as a consequence of war head injury. Mil Med 2002;167:666-70.

26. Ozkan U, Kemaloğlu S, Ozateş M, Aydin MD. Analysis of 107 civilian craniocerebral gunshot wounds. Neurosurg Rev 2002;25:231-6. [CrossRef]
27. Abdolvahabi RM, Dutcher SA, Wellwood JM, Michael DB. Craniocerebral missile injuries. Neurol Res 2001;23:210-8. [CrossRef]

28. Karasu A, Cansever T, Sabanci PA, Kiriş T, Imer M, Oran E, et al. Craniocerebral civilian gunshot wounds: one hospital's experience. [ Article in Turkish]. Ulus Travma Acil Cerrahi Derg 2008;14:59-64.

29. Ecklund JM, Sioutos P. Prognosis for gunshot wounds to the head. World Neurosurg 2014;82:27-9. [CrossRef]

30. Ansari SA, Panezai AM. Penetrating craniocerebral injuries: an escalating problem in Pakistan. Br J Neurosurg 1998;12:340-3. [CrossRef]

31. Yildizhan A, Paşaoğlu A, Gök AV, Aral O. Surgical management of craniocerebral gunshot wounds. Neurosurg Rev 1992;15:45-50. [CrossRef]

32. Gönül E, Akbörü M, Izci Y, Timurkaynak E. Orbital foreign bodies after penetrating gunshot wounds: retrospective analysis of 22 cases and clinical review. Minim Invasive Neurosurg 1999;42:207-11. [CrossRef]

\section{ORIJINAL ÇALIŞMA - ÖZET}

Kranyoserebral ateşli silah yaralanmalarında prognostik faktörler: Nöroşirüriji bakış açısından 30 hastanın analizi

\section{Dr. Alparslan Kırık, Dr. Soner Yaşar, Dr. Mehmet Ozan Durmaz}

Sağlık Bilimleri Üniversitesi Gülhane Tıp Fakültesi, Beyin ve Sinir Cerrahisi Anabilim Dalı, Ankara

AMAÇ: Kranyoserebral ateşli silah yaralanmaları (KASY), kranyumun en ölümcül yaralanmalarıdır. Çoğunlukla askeri çatışmalara sekonderdir. Bu yaralanmaların ayrıca epilepsi, hidrosefali, enfeksiyon ve geç dönem bilişsel işlev bozuklukları gibi ciddi sonuçları da vardır. Çalışmamızın amacı, kliniğimizin KASY serisini sunmak ve bu yaralanmaların sonuçlarını ve prognostik faktörlerini tartışmaktır.

GEREÇ VE YÖNTEM: 20I I-2019 yılları arasında bölümümüzde KASY tanısı ile tedavi edilen hastalar geriye dönük olarak incelendi. Yaralanma tipleri, yerleri, cerrahi tedavileri ve sonuçları analiz edildi. Radyolojik değerlendirme de yapıldı.

BULGULAR: Otuz hasta KASY tanısı ile tedavi edildi. Bunların hepsi erkekti ve yaş ortalaması 27.9 idi. Frontal lob I2 (\%40) hastada etkilenirken, sekiz hastada temporal lob, altı hastada oksipital lob, üç hastada parietal lob ve bir hastada posterior fossa etkilendi. Yirmi üç hastaya cerrahi tedavi uygulandı. On üç hasta (\%43.3) cerrahi veya tıbbi tedaviye rağmen kaybedildi.

TARTIŞMA: Kranyoserebral ateşli silah yaralarında ölüm oranı yüksektir. Ventriküler yaralanma, bihemisferik yaralanma, perforan yaralanma, beyin sapı hasarı ve başvuru anında düşük GKS skoru prognostik faktörlerdir. Daha iyi klinik sonuçlar elde etmek için uygun ve doğru hasta yönetimi zorunludur.

Anahtar sözcükler: Ateşli silah; cerrahi; kranioserebral; sonuç; yaralanma.

Ulus Travma Acil Cerrahi Derg 2020;26(6):859-864 doi: 10.14744/tjtes.2020.89947 